\title{
Concentration Divided by Dose
}

National Cancer Institute

\section{Source}

National Cancer Institute. Concentration Divided by Dose. NCI Thesaurus. Code C102368.

The concentration divided by dose. 